\title{
Exchange Rates Under The East Asia Dollar Standard: The Future Of East Asian Economies
}

Ordean Olson, (E-mail: olson@nova.edu), Nova Southeastern University

\begin{abstract}
The effects of fluctuations in the yen/dollar exchange rate on the business cycle of the smaller East Asian economies are examined in this paper. The cointegration error-correction model is employed to examine the nature of the interrelationship between the yen/dollar exchange rate and the economic stability of the East Asian countries. The empirical results reveal strong and lasting effects of changes in the yen/dollar exchange rate on the economic income and exchange rate stability of the East Asian countries. The results also indicate that stabilizing the yen/dollar exchange rate with the East Asian business cycle would benefit Japan as well as the economies of East Asia.
\end{abstract}

\section{INTRODUCTION}

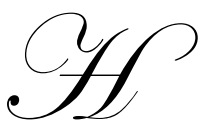

ong Kong, Indonesia, Korea, Malaysia, Philippines, Singapore, Taiwan and Thailand all pegged their exchange rates to the U.S dollar before the 1997-1998 Asian currency crisis. China joined the system in 1994 adopting a stable peg to the dollar. These countries used different exchange rate systems, however, they all pegged to the dollar. This provided an informal common monetary standard that enabled this region to maintain economic stability (McKinnon 2005).

This monetary standard collapsed during the crisis. China and Hong Kong retained their dollar pegs while Indonesia, Korea, Malaysia, Philippines and Thailand let their currencies fall when they were attached. During 1997 through mid-1998 Japan let the yen float downward substantially and the crisis increased for the other East Asian economies.

The East Asian currencies predominantly weighted in dollars have returned to their pre-crisis exchange rate stability against the dollar. In addition, most of the East Asian governments have accumulated funds of official dollar reserves. However, (Fisher 2001) has argued soft pegs are not sustainable for emerging markets, which are open to international capital flows. (Mussa 2000) argues against restoring pre-1997 regime soft dollar pegs.

Dollar pegging is favored by (McKinnon 2005) for the East Asian economies, but emphasizes two major problems. One involves the problem of extreme exchange rate fluctuations between the dollar and other major currencies. The other is moral hazard whereby banks or firms prefer to gamble rather than hedge their exchange rate risk.

East Asian countries with the exception of Japan returned to their pre-crisis format of pegging to the dollar. China recently abandoned the peg of its currency to the dollar and is now linking the yuan to a basket of currencies. With the exception of Indonesia, the other East Asian countries pursue pegs to the dollar (Japan excluded). The dollar is the dominant currency for the smaller East Asian economies for their intraregional trade and capital flows. This allows them to reduce payment risk and to control their domestic price levels.

The Eastern Asia economies are very open because of the importance of their exports and their relatively small size. While international trade has been a critical factor in their economic success, it also increases their vulnerability to shocks such as the yen/dollar exchange rate. 
Japan has chosen to accept a position where its currency varies widely against the U.S dollar (McKinnon and Ohno 1997). Fig 1 shows how the yen has varied against the dollar since 1971. The yen has appreciated from 360 yen/dollar to around $106 \mathrm{yen/dollar}$ in early 2003. Even though the trend of continual yen appreciation seemingly ended in 1995, fluctuations in the yen/dollar exchange rate have been prevalent in the last 10 years. Fig 2 shows the large variations in the yen/dollar exchange rate since 1990 and real growth rates in the East Asian economies.

Figure 1. Yen/Dollar Exchange Rate

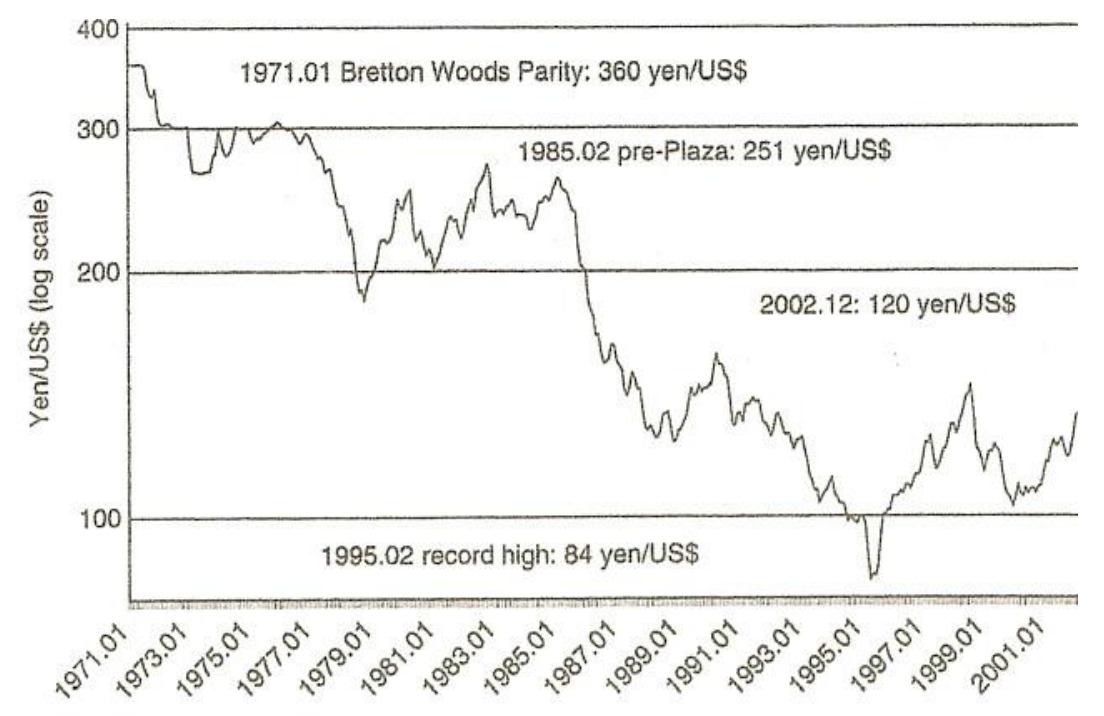

Figure 2.2

Yen/U.S. Dollar Exchange Rate, 1971-2002 (Monthly). (International Monetary Fun International Financial Statistics)

(Kwan 2001) suggests that the yen/dollar exchange rate affects the output of the East Asian economies in both trade and foreign direct investment. When the East Asian economies keep their exchange rates stable against the U.S. dollar they must cope with extreme fluctuations of the dollar against the yen. During the crisis of 1997, the currencies of Indonesia, Korea, Malaysia, Philippines and Thailand were attacked. They had to end their dollar pegs and allow their currencies to depreciate. Singapore and Taiwan also followed with currency depreciations. However, Japan's currency depreciated by more than 30\% during the 1997-1998 time period. (McKinnon 2001a) argued that this resulted in severe deflationary pressures on the dollar prices of goods and services traded in the region.

The wide fluctuations in the yen/dollar rate over the last 20 years or more have created and influenced a business cycle in the smaller East Asian economies (ASEAN4) (Kwan 2001). He argues that the East Asian exchange rates are still susceptible to the fluctuating yen/dollar exchange rate.

There are positive effects when the yen appreciates. For example, the Japanese FDI increases and the other East Asian countries exports become more competitive against Japan's exports. However, when the yen depreciates against the dollar (1997-1998), their output decreases, FDI from Japan decreases and their exports become less competitive.

A pressing problem is the excess buildup of foreign exchange assets, which results in conflicted virtue

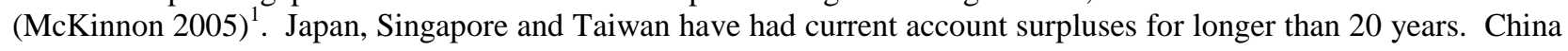
has had modest current account surpluses since 1995 and large surpluses since 2000. Even the Asian economies have become creditors since 1997 and have had trade surpluses. Figure 3 shows the comparison of East Asia and U.S Current Account surpluses for the 1900-2003 period. 
This paper will examine the effects of fluctuations of the yen/dollar exchange rate on the business cycle in the smaller East Asian economies. This study will investigate if the effect of an external shock to the East Asian economies, such as a yen/dollar exchange rate shock, is weaker since the Asian currency crisis of 1997 or if the effects are still present.

\section{METHODOLOGY}

Using VECM models, the study focuses especially on the effects of a yen/dollar shock on economic output and exchange rates of the smaller East Asian economies of Hong Kong, Indonesia, Malaysia, Philippines, Singapore, Taiwan and Thailand.

Figure 2. East Asia Business Cycle And The Yen/Dollar Exchange Rate

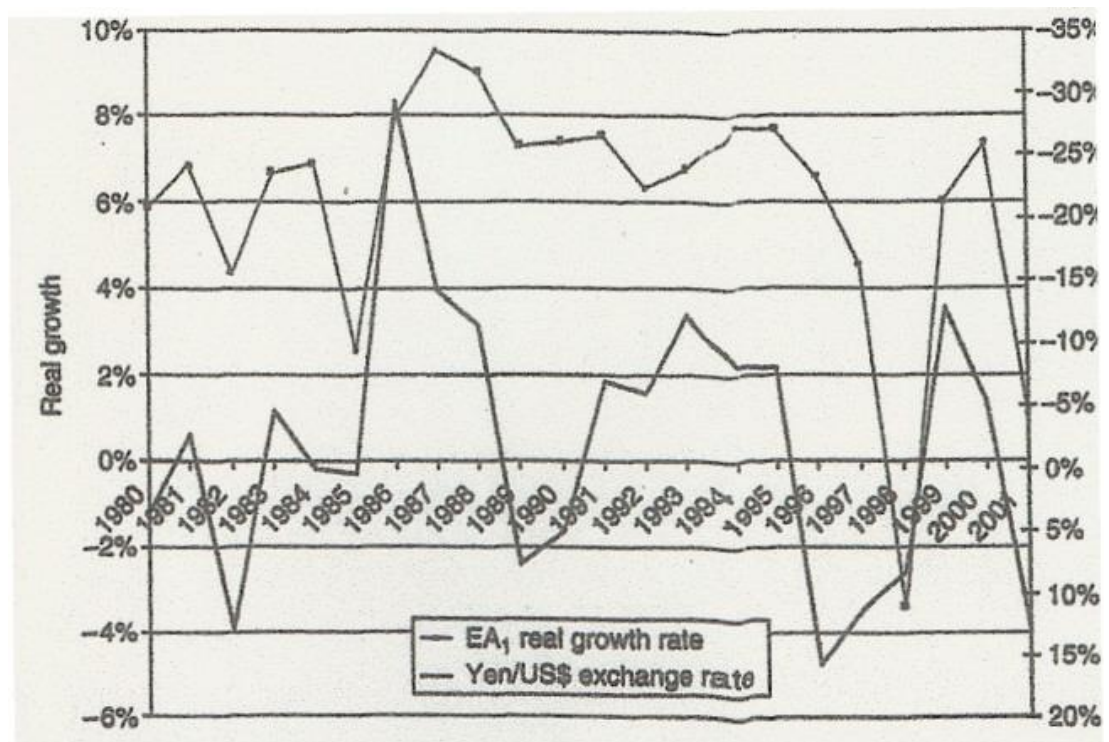

Figure 2.6

Bast Asia $\left(E A_{1}\right)$ Business Cycle and the Yen/U.S. Dollar Exchange Rate, 1980-2 (Yearly). EA $A_{1}$ comprises Hong Kong, Indonesia, Korea, Malaysia, Philippines, Singap Taiwan, Thailand. (International Monetary Fund, Intenzational Financial Statistics; Cen Rank of China)

The study will employ the following variables: the yen/dollar exchange rate, the GDP of the Asean 4 economies (Indonesia, Malaysia, Philippines and Thailand), and the GNP of the Newly Industrial economies (Hong Kong, Korea, Singapore, and Taiwan). This breakdown follows the IMF statistics format in the data collected from the International Financial Statistics (IFS). The model is than extended later in the study to include nine additional variables: the exchange rates of the Asean4 economies and the exchange rates of the Newly Industrial economies for a total of twelve variables. The additional variables are included to more fully examine the nature of the interrelationship between the yen/dollar exchange rate and the economic stability of the East Asian countries.

The data set (the yen/dollar exchange rate, the GNP of the Asean4 economies and the GNP of the Newly Industrial economies) is from International Financial Statistics (IFS). The sample period is from 1990 to 2005. Monthly data was used to increase the degree of freedom.

The specification of each variable to be used in our VECM model was determined by the use of DickeyFuller (ADF) unit root tests. Table 1 reveals that the tests fail to reject the null hypothesis of the unit root at the $1 \%$ 
significance level for all series. However, the null hypothesis is rejected and the variables are found to be stationary when the series is differenced.

The Johansen test (table 2) reveal that no cointegrating relations exist when applied to the yen/dollar exchange rate, the GNP of the Asean4 economies and the GDP of the Newly Industrial economies.

The model employed the first three variables in the following order: the first difference of the log of GDP of the Asean 4 economies, the first difference of the GDP of the Newly Industrialized economies and the first difference of the log of the yen/dollar exchange rate.

The objective of this paper is to study the relationship of the above variables during the pre-crisis and the post-crisis period. In fact, some studies suggested that some East Asian countries have changed greatly since the currency crisis in 1997 (Kwan, 2001) (Urata, 2001). In this regard, we arbitrarily selected the break point as August 1997, which is the date of the beginning of the crisis in East Asia. We therefore divide our sample period into two periods. The first beginning in 1990 and ending in August 1997. The second beginning in August 1997 and ending in 2005.

Regarding the structure of our VECM model, we put the variable yen/dollar exchange rate first as it is assumed to be exogenous to the East Asian4 and the Newly Industrial economies GDP'S and exchange rates.

\section{IMPULSE RESPONSES}

Hopefully the study will answer three questions. How do the East Asian 4 and Newly Industrial economies exchange rates and GDP'S react to changes in the yen/dollar rate? How persistent and strong are these effects? Is there any difference between the periods before and after the Asian currency crisis?

Impulse responses were employed and examined to answer these questions. The results suggest that the depreciation rate of the currencies against the dollar increases for several months. The increase in the rate of depreciation is significant in the first two months, but not significant after three months, and approaches zero after six months. The point estimate shows that the impact effect is about $0.24 \%$. The responses of the currencies against the dollar after the crisis reveal the depreciation rate of the currencies against the dollar increases $1.5 \%$ on impact, $1 \%$ in the next month, then eventually reaches zero over time. From the second month after the shock, the responses are not significantly different from zero.

To summarize, the results for the period after the currency crisis suggest that the currencies exchanges rates response becomes stronger and the speed of the adjustment tends to increase. The response of the first difference of the log of the GDP'S (Asean4 and NIC) to a one standard deviation change in the first difference of the log of the yen/dollar rate before the 1997 Asian currency showed the GNP'S of the economies increased by $0.01 \%$ on impact. This was followed by decreases of $0.03 \%$ in the next month in response to the depreciation of the yen against the dollar. However, the responses are far from significant at the 95\% level. The impulse responses after the 1997 Asian currency crisis revealed GDP's decreased by $0.2 \%$ on impact and decreased further by $0.25 \%$ in the next month. The responses are significant at the 95\% level. The responses are lower at a lower significance level during the pre-crisis period, but greater during the post-crisis period and at a higher significance level.

\section{VARIANCE DECOMPOSITION}

Tables 3 and 4 report the results of the variance decomposition of each variable. The results show that the yen/dollar exchange rate shocks explain $12.22 \%$ of the economies exchange rate variation during the pre-crisis period but $10.39 \%$ during the post-crisis period. The results suggest that the yen/dollar shocks to fluctuation in the economies GNP'S increases dramatically in the post-crisis period compared to the pre-crisis. The change increases from $0.33 \%$ in the pre-crisis period to $11.16 \%$ during the post-crisis period. 


\section{MODEL CHECKING}

The model was tested for residual autocorrelation and conditional heteroskedasticity. The results of the Breusch-Godfrey test and the ARCH tests are shown in table 5. The results show that the model is stable.

\section{EXTENDED MODELS}

To determine the robustness of the findings the model was extended into a fifteen variable model. Trade balances, inflation rates and capital accounts of the Asean 4 economies were included in the model.

The stability tests revealed that the inflation rate and trade balance are not stationary, while the capital account is stationary. The results of the Johansen test suggests that the there are no co-integration relationships for the model. The trade balances and inflation rates of the economies are included in a difference form based on these tests, while the capital account of the economies is included in a level form because it is stationary. Figures 6 and 7 reveal the results for the model, which include the additional variables.

The transmission process can be determined from the responses of the additional variables to the depreciation of the yen/dollar exchange rate. There will be a possible decline in the competitiveness of Asean 4 and Newly Industrial countries exporters in relation to Japanese exporters. The empirical analysis of Japanese exporter's exchange rate policies by Froot and Llemperer (1989), Knetter (1993) and Klitgaard (1999) indicate slight differences exist compared with other countries, but Japanese companies do change their export prices in response to fluctuations in the exchange rate. Thus when the yen depreciates, the competitiveness of the Asean 4 and Newly Industrialized economies products weaken against the Japanese counterparts. The results in Figure 4 suggest that the East Asia exports are affected by the changes in the yen/dollar exchange rate.

When the yen depreciated against the dollar, the inflation rates increased at the 95\% confidence level in the pre-crisis period, but the strongest impact was in the post-crisis period. Calvo and Reinhart (2002) argue that the common peg to the dollar helps anchor any one country's price level because a high proportion of world trade is invoiced in dollars. Pegging to the U.S. dollar allowed the developing countries of East Asia prior to the crisis period to maintain low or moderate inflation. However, when Indonesia, Korea, Malaysia, Philippines and Thailand were suddenly forced to devalue and curtail imports while trying to stimulate exports during the crisis period, there was a deflation.

The deterioration in capital accounts following the yen/dollar depreciation may be an important reason for the decrease in the GDP of the Asean 4 and NIT economies in the post-crisis period. Figure 8 shows a decrease in the capital account in response to depreciation of the yen/dollar rate in the period immediately following the crisis period. Kamin (2005) argues that the Asean4 economies have been trying to maintain the competitiveness of their exports. However, he believes that these policies will be difficult to maintain in the foreseeable future. He agues that the recent large current account surpluses in the region will also decline in the future. Figure 3 shows today's current account surpluses are large but only after the crisis. The region's economies were in balance from 1980 to 1997, even though these countries pursued export growth strategies during this period.

\section{CONCLUSIONS}

The VECM analysis revealed that a decline in the yen/dollar exchange rate was followed by a decline in the GNP'S of the East Asian economies. This was not significant during the pre-crisis period, but significant during the post-crisis period. The forecast error variance decomposition revealed that the yen/dollar rate shocks accounted for only $0.33 \%$ of the change in the GNP of the economies at the six-month level during the pre-crisis period. However, they accounted for $11.16 \%$ at the six-month level for the post-crisis period. This suggests that fluctuations in the yen/dollar exchange rate have an influence on the economic output of the East Asian economies. 


\section{NOTES}

(McKinnon 2005) refers to conflicted virtue when an international creditor cannot lend in its own currency and then results in a currency mismatch.

\section{REFERENCES}

1. Calvo, Guillermo and Carmen Reinhart. 2002. Fear of Floating. Quarterly Journal of Economics 117: 379408.

2. Eichengreen, Barry. 2004. Global and the Lessons of Bretton Woods. Working Paper 10497. National Bureau of Economic Research, Cambridge, May 2004.

3. Fisher, Stanley. 2001. Exchange Rate Regimes: Is the Bipolar View Correct? Journal of Economic Perspectives 15:3-24.

4. Frankel, Jeffrey A. and Shang-Jim Wei. 1994. Yen Block or Dollar Bloc? Exchange Rate Policies in East Asian Economies. In Macroeconomic Linkage: Savings, Exchange Rates, and Capital Flows, ed. Takatoshi Ito and Anne Krueger, 295-329. Chicago: University of Chicago Press.

5. Friedman, Milton. 1953. The Case for Flixible Exchange Rates. In Essays in Positive Economics, 157-203. Chicago: University of Chicago Press.

6. Froot, Kenneth A. and Jeremy C. Stein. 1991. Exchange Rates and Foreign Direct Investment: An Imperfect Capital Market Approach? Quarterly Journal of Economics 106: 1191-1217.

7. Kamin, Steven, 2005. The Revived Bretton Woods system: Does It Explain Developments in Non-China Developing Asia? Presentation for conference on The Revived Bretton Woods System: A New Paradigm for Asian Development. Federal Reserve Bank of San Francisco, February 4, 2005.

8. Kwan, C. H. 2001. Yen Block: Toward Economic Integration in Asia. Washington, D.C.: Brookings Institution

9. McKinnon, Ronald L. and Kenichi Ohno, 1997. Dollar and Yen: Resolving Economic Conflict between the United States and Japan. Cambridge, Mass: MIT Press.

10. McKinnon, Ronald L. and Tungher Schnabl. 2003. Synchronized Business Cycles in East Asia: Fluctuations in the Yen/Dollar Exchange Rate. The World Economy 26 (August): 1067-1088.

11. McKinnon, Ronald L., 2001a. After the Crisis, the East Asian Dollar Standard Resurrected: An Interpretation of High Frequency Exchange Rate Pegging. In Rethinking the East Asian Miracle, ed. Joseph E. Stiglitz and Shahid Yusuf, 197-246. New York: Oxford University Press

12. 1963. Capital Mobility and Stabilization Policy under Fixed and Flexible Exchange Rates. Canadian Journal of Economics and Political Science 29: 475-485.

13. 1968. International Economics. New York: Macmillan.

14. 2004. The World Dollar Standard and Globalization: New Rules for the Game? In exchange Rates, Economic Integration and the International Economy, ed. Leo Michaelis and Mark Lovewell, 3-28. Toronto: APF Press.

15. - 2005. Exchange Rates Under The East Asian Dollar Standard. Cambridge, Mass. MIT

16. Mundell, Robert A. 1961. A Theory of Optimum Currency Areas. American Economic Review 51 (November): 509-517

17. Mussa, Michael, Paul Masson, Alexander Swoboda, Esteban Jadresic, Plulo Mauro, and Andy Berg. 2000. Exchange Rate Regimes in an Increasingly Integrated World Economy. International Monetary Fund Occasional Paper 193.

18. Obstfeld, M. and Kenneth Rogoff. The Unsustainable U.S. Current Account Position Revisited. 2004 NBER pre-conference on G-7 Current Account Imbalances: Sustainability and Adjustment.

19. Urata, Shujiro. 2001. Emergence of an FDI-Trade Nexus and Economic Growth in East Asia. In Rethinking the East Asian Miracle, ed. Joseph E. Stiglitz and Shahid Ysiuf, 409-459. New Your: Oxford University Press. 


\section{APPENDIX}

Table 1. Stationary tests

\begin{tabular}{lcc}
\hline & ADF unit root test & Schmidt Phillips unit root test \\
\hline Log of yen/dollar exchange rate & -2.78 & -.832 \\
First difference of log of yen/dollar exchange rate & $-7.32^{* *}$ & $-123.36^{* *}$ \\
Log of ringgit/dollar exchange rate & -2.04 & -5.77 \\
Log of rupiah/dollar exchange rate & -2.20 & -5.53 \\
Log of peso/dollar exchange rate & -2.91 & -13.49 \\
Log of baht/dollar exchange rate & -2.32 & -6.86 \\
First difference of ringgit/dollar exchange rate & $-5.70^{* *}$ & $-123.36^{* *}$ \\
First difference rupiah/dollar exchange rate & $-4.28^{* *}$ & $-101.55^{* *}$ \\
First difference peso/dollar exchange rate & $-5.50^{* *}$ & $-135.79^{* *}$ \\
First difference baht/dollar exchange rate & $-4.76^{* *}$ & $-105.70^{* *}$ \\
Log of Asean4 output & $-3.24^{\mathrm{y}}$ & -2.21 \\
First difference of Asean4 output & $-3.19^{\mathrm{Y}}$ & $-36.94^{* *}$ \\
Log of Newly Industrialized economies output & -1.0871 & -4.3093 \\
First difference of Newly Industrialized economies output & $-4.9901^{* *}$ & $-92.0364^{* *}$ \\
Log of Japan output & $-5.1724^{* *}$ & -0.7991 \\
First difference of Japan output & $-7.2621^{* *}$ & $-272.4694^{* *}$ \\
\hline
\end{tabular}

Notes:

1. The significance levels of the ADF are 1\%: $-3.96,5 \%:-3.41$.

2. The significant levels of the Schmidt Phillips are $1 \% ;-25.2,5 \% ;-18.1$

3. Four lags are used in the ADF and Schmidt Phillips unit root tests.

4. ${ }^{y}, *$ and $* *$ denote statistical significance at the $10 \%, 5 \%$ and $1 \%$ respectively.

Table 2. Johansen Test

\begin{tabular}{llcccc}
\hline $\mathrm{R}_{\mathrm{o}}$ & $\begin{array}{l}\text { Likelihood } \\
\text { ratio }\end{array}$ & $10 \%$ Critical value & $5 \%$ Critical value & 1\%Critical value & $\begin{array}{l}\text { Hypothesized } \\
\text { Number of } \\
\text { co- integrating } \\
\text { equations }\end{array}$ \\
\hline 0 & 89.28 & 90.01 & & None \\
1 & 58.07 & 65.73 & 95.51 & 104.36 & at most 1 \\
2 & 36.64 & 44.45 & 69.61 & 77.29 & at most 2 \\
3 & 17.43 & 27.16 & 47.71 & 54.23 & at most 3 \\
4 & 8.08 & 13.42 & 29.80 & 35.21 & at most 4 \\
\hline
\end{tabular}

Note: $*$ and $* *$ denote statistical significance at the $5 \%$ and $1 \%$ levels, respectively.

Table 3. Variance Decomposition

\begin{tabular}{lllll}
\hline \multicolumn{2}{l}{ Yen/dollar exchange rate (Jan 1990-August 1997) } \\
\hline \multirow{2}{*}{ Period } & Standard & First difference of & First difference of & First difference of log of New \\
& Error & $\log$ of Asean4 output & $\log$ of Ind/dollar & Industrial economies Output \\
\hline 1 & 0.01 & 0.00 & 41.2 & 0.00 \\
3 & 0.01 & 0.01 & 43.4 & 0.03 \\
6 & 0.01 & 0.02 & 45.5 & 0.04 \\
\hline
\end{tabular}


Table 4. Variance Decomposition

\begin{tabular}{lllll}
\hline \multicolumn{2}{l}{ Yen/dollar exchange rate (August 1997-July 2005) } \\
\hline \multirow{2}{*}{ Period } & Standard & First difference of & First difference of & First difference of log of New \\
& Error & $\log$ of Asean 4 output & $\log$ of Ind/dollar & Industrial economies \\
\hline 1 & 0.01 & 0.00 & 9.40 & 0.00 \\
3 & 0.01 & 0.03 & 11.8 & 0.03 \\
6 & 0.01 & 0.10 & 13.6 & 0.12 \\
\hline
\end{tabular}

Table 5. Diagnostics Of AR (4) Model For Output Series Tests For Residual Autocorrelation $\mathrm{LM}_{2}$

\begin{tabular}{lllllll}
\hline & Before 1997 & \multicolumn{5}{c}{ After 1997 } \\
\hline & Asean4 & Newly Ind & Japan & Asean4 & Newly Ind & Japan \\
\hline Test statistic & 5.4168 & 7.3429 & 5.3472 & 18.3211 & 10.9607 & 8.1724 \\
$p$-values & 0.7122 & 0.5002 & 0.7199 & 0.0189 & 0.2039 & 0.4168 \\
df: & 8.0000 & 8.0000 & 8.0000 & 8.0000 & 8.0000 & 8.0000 \\
\hline
\end{tabular}

Other Diagnostics ARCH (4) Model For Output Series

\begin{tabular}{|c|c|c|c|c|c|c|}
\hline & $\begin{array}{l}\text { Before } 1997 \\
\text { Asean4 }\end{array}$ & Newly Ind & Japan & $\begin{array}{l}\text { After } 199 \\
\text { Asean4 }\end{array}$ & Newly Ind & Japan \\
\hline Test statistic & 2.5247 & 2.0678 & 2.4774 & 1.9717 & 0.6843 & 1.4433 \\
\hline$p$-values & 0.6276 & 0.7098 & 0.0364 & 0.8747 & 0.9512 & 0.8314 \\
\hline F statistic & 0.6515 & 0.5361 & 0.6389 & 0.3032 & 0.1732 & 0.3670 \\
\hline
\end{tabular}

In table 5, diagnostic tests for the AR(4) model of the output series are given with $p$-values. The $p$-value represents the probability of getting a test value greater than the observed one if the null hypothesis is true. Hence, the null hypothesis is actually rejected only for $p$-values smaller than 0.1 or 0.05 . In the present case, all $p$-values are relatively large; consequently, none of the diagnostic tests indicate problems with the model.

Table 6. Johansen Test

\begin{tabular}{llllll}
\hline $\mathrm{R}_{\mathrm{o}}$ & Likelihood & $10 \%$ Critical value & $5 \%$ Critical value & $1 \%$ Critical Value & $\begin{array}{l}\text { Hypothesized } \\
\text { number of } \\
\text { Co-integrating } \\
\text { equations }\end{array}$ \\
\hline 0 & 19.05 & 23.32 & & & none \\
1 & 4.44 & 10.68 & 25.73 & 30.67 & at most 1 \\
\hline
\end{tabular}

Note: This analysis was conducted after including Asean 4 trade balance as the $12^{\text {th }}$

variable. $*$ and $* *$ denote statistical significance at the $10 \%, 5 \%$ and $1 \%$ levels, respectively.

Table 7. Johansen Test

\begin{tabular}{llllll}
\hline $\mathrm{R}_{\mathrm{o}}$ & Likelihood & $10 \%$ Critical value & $5 \%$ Critical value & $1 \%$ Critical Value & $\begin{array}{l}\text { Hypothesized } \\
\text { number of } \\
\text { Co-Integrating } \\
\text { equations }\end{array}$ \\
\hline 0 & 18.25 & 17.98 & & none \\
1 & 1.46 & 7.60 & 20.16 & 24.69 & at most 1 \\
\hline
\end{tabular}

Note: This analysis was conducted after including Asean 4 current account as the $13^{\text {th }}$ variable. $*$ and $* *$ denote statistical significance at $10 \%, 5 \%$ and $1 \%$ levels, respectively. 
Table 8. Johansen Test

\begin{tabular}{llllll}
\hline $\mathrm{R}_{\mathrm{o}}$ & Likelihood & $10 \%$ Critical value & $5 \%$ Critical value & $1 \%$ Critical Value & $\begin{array}{l}\text { Hypothesized } \\
\text { number of } \\
\text { Co-Integrating } \\
\text { equations }\end{array}$ \\
\hline 0 & 15.73 & 17.97 & & none \\
1 & 5.91 & 7.60 & 20.16 & 24.69 & at most 1 \\
\hline
\end{tabular}

Note: This analysis was conducted after including Asean4 inflation as the $14^{\text {th }}$ variable. $*$ and $* *$ denote statistical significance at $10 \%, 5 \%$ and $1 \%$ levels, respectively.

Figure 3. Non-China Developing Asia: Current Account (\$Billions)

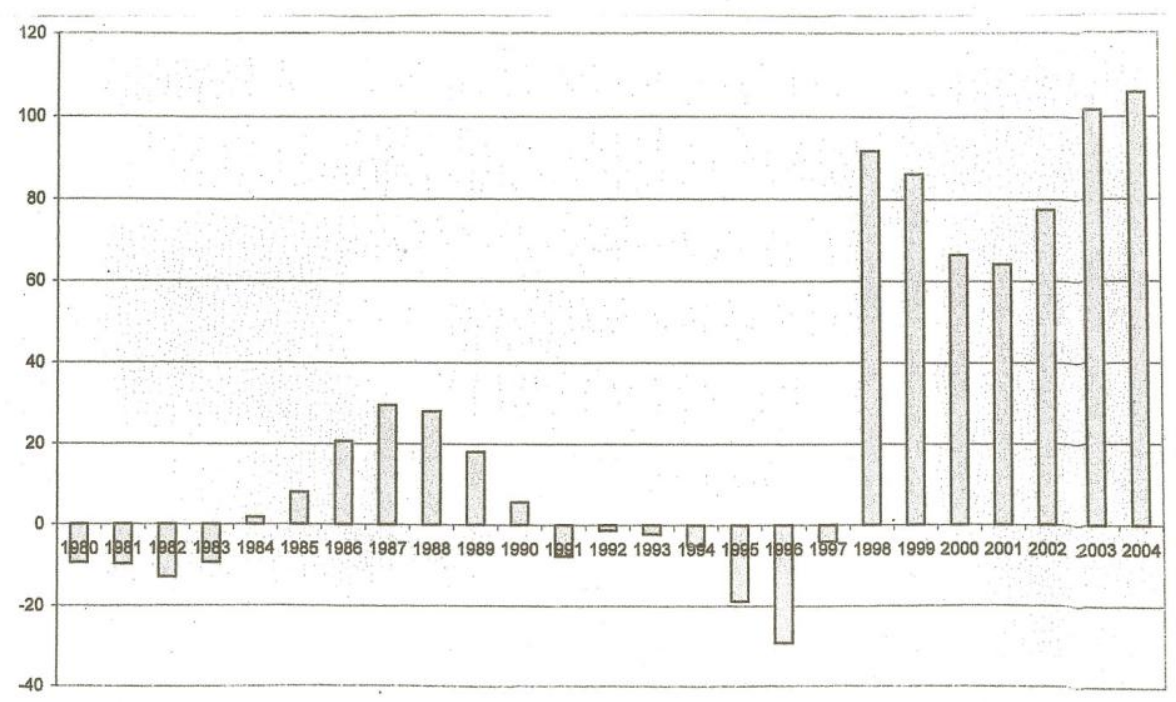

*2004 is based on national sources for Korea, Singapore, and Thailand; and September 2004 IMF WEO Database for all else. 
Figure 4. East Asia Exports And The Yen/Dollar Exchange Rate

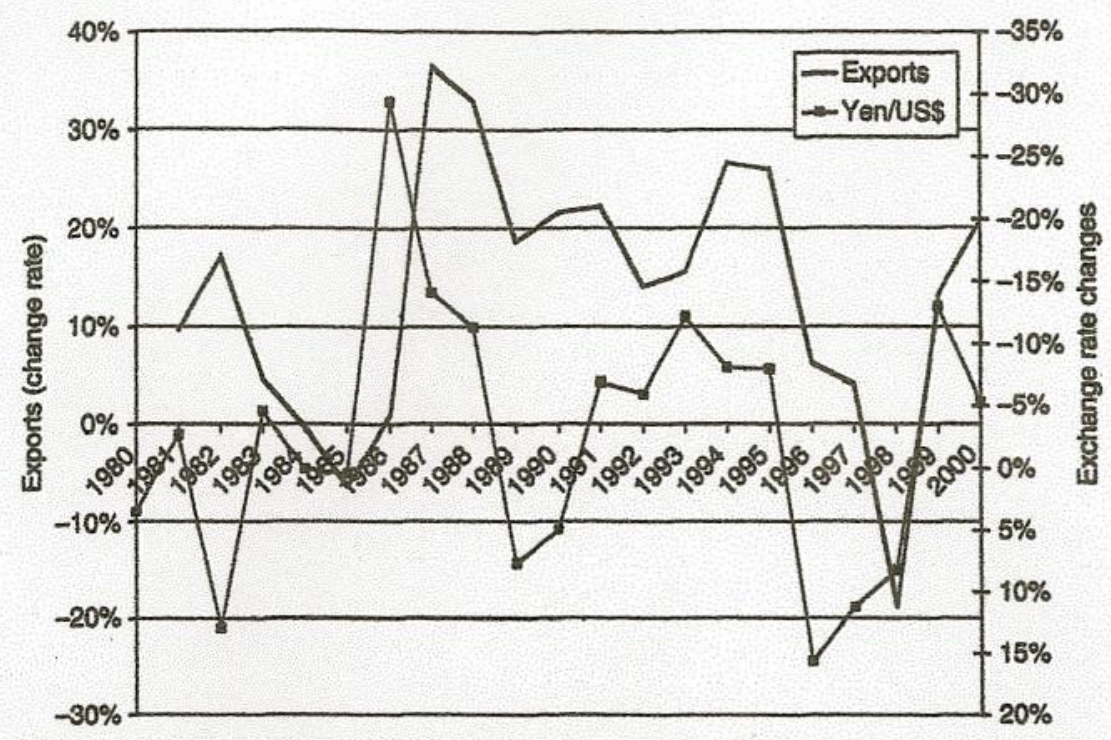

Figure 2.4

Bast Asia (EA $)$ Exports and the Yen/U.S. Dollar Exchange Rate, 1980-2001 (Yeariy). EA $_{1}$ comprises Hong Kong, Indonesia, Korea, Malaysia, Philippines, Singapore, Taiwan, Thailand. (International Monetary Fund, International Financial Statistics) 
Figure 5. 1980-1997 Response To One S.D. Log Yen/Dollar Exchange Rate.

(Before Currency Crisis

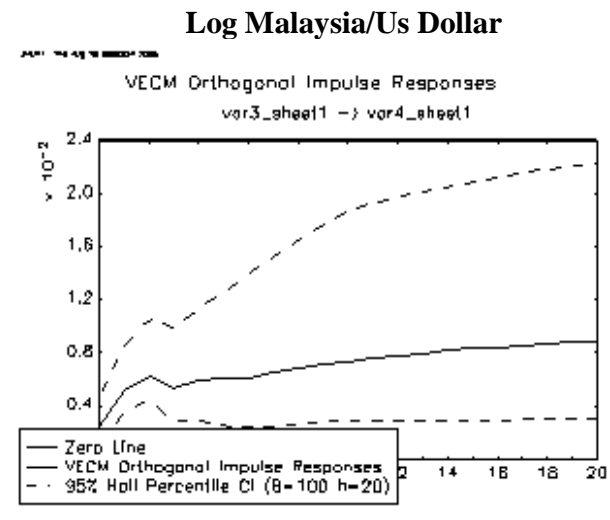

Log Indonesia/Us Dollar
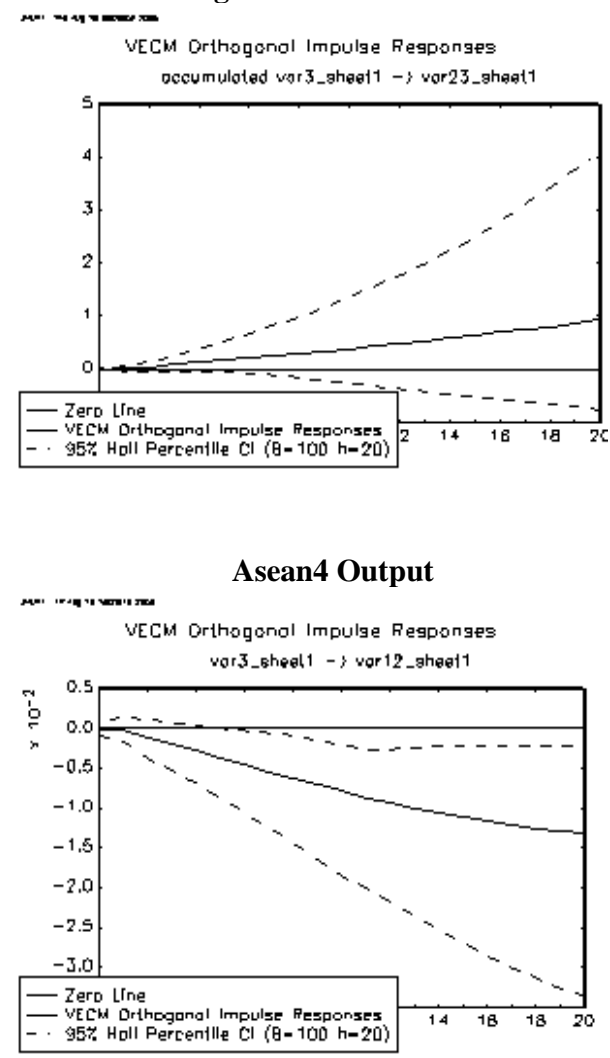
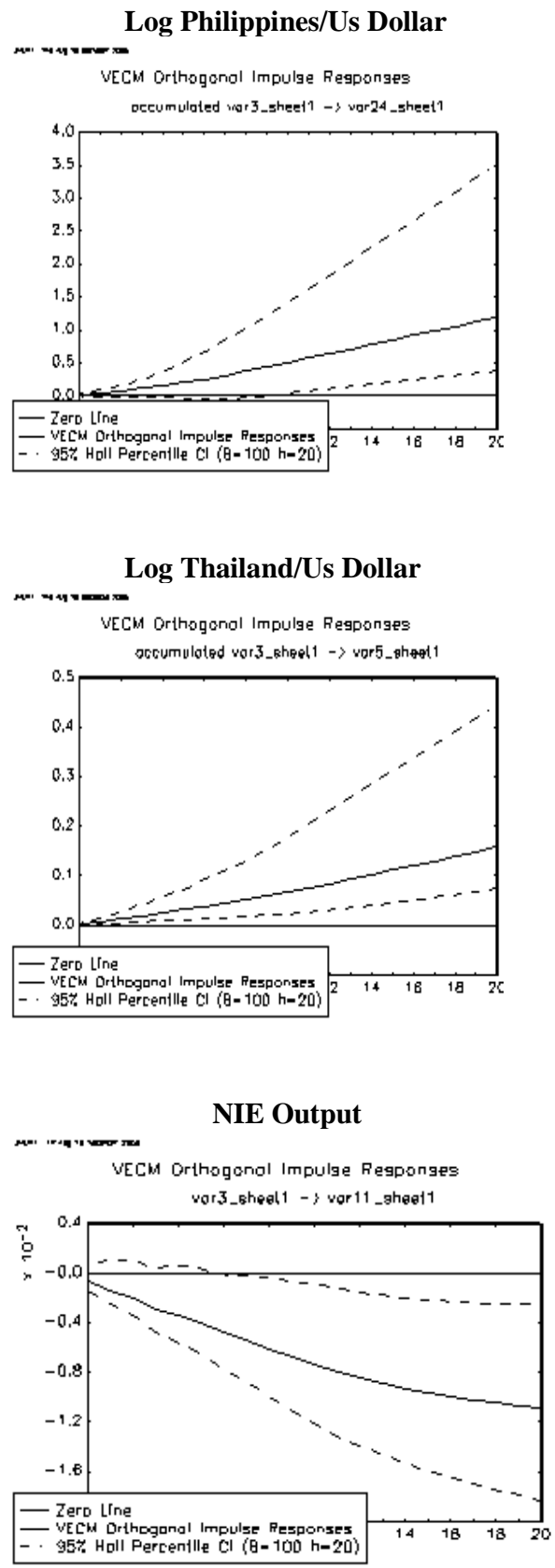
Figure 6. 1997-2005 Response To One S.D. Log Yen/Dollar Exchange Rate (After Currency Crisis)
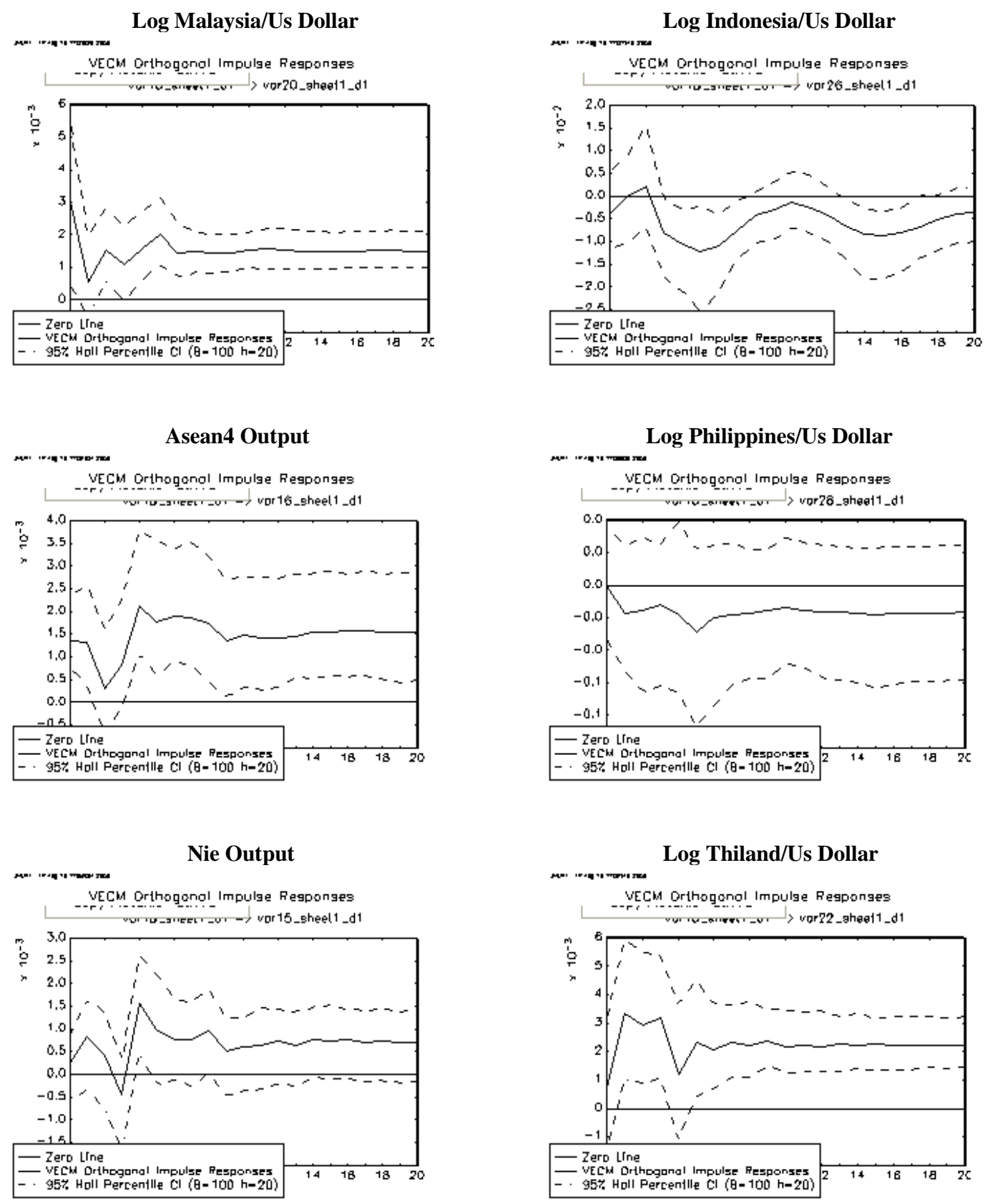
Response To One S.D. Log Yen/Us Dollar Exchange Rate.

(1980-1997)

\section{Asean4 Trade}

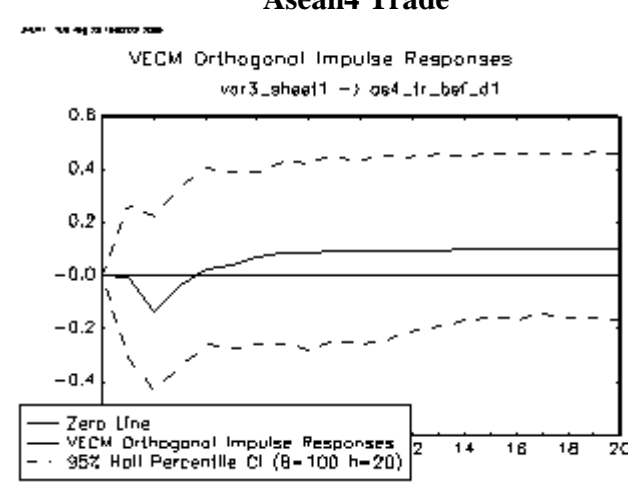

Asean4 Inflation
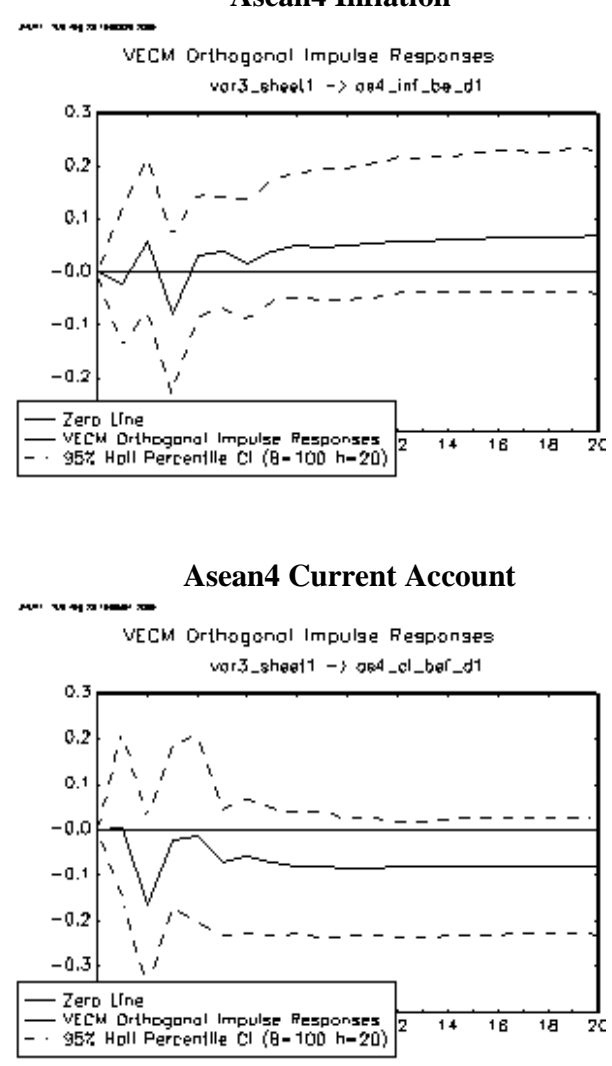

Figure 7
(1997-2005)

Asean4 Trade

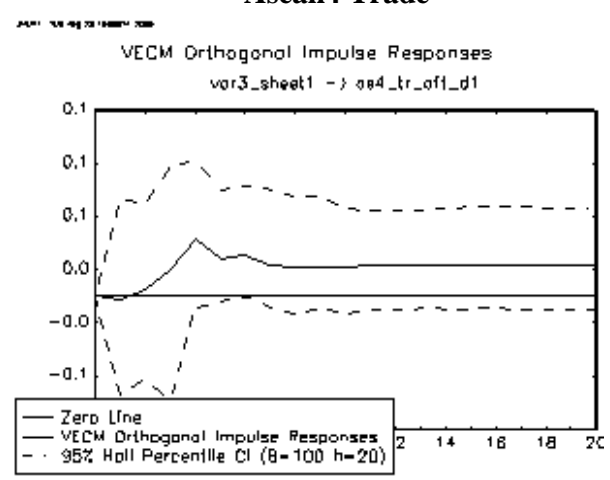

Asean4 Inflation
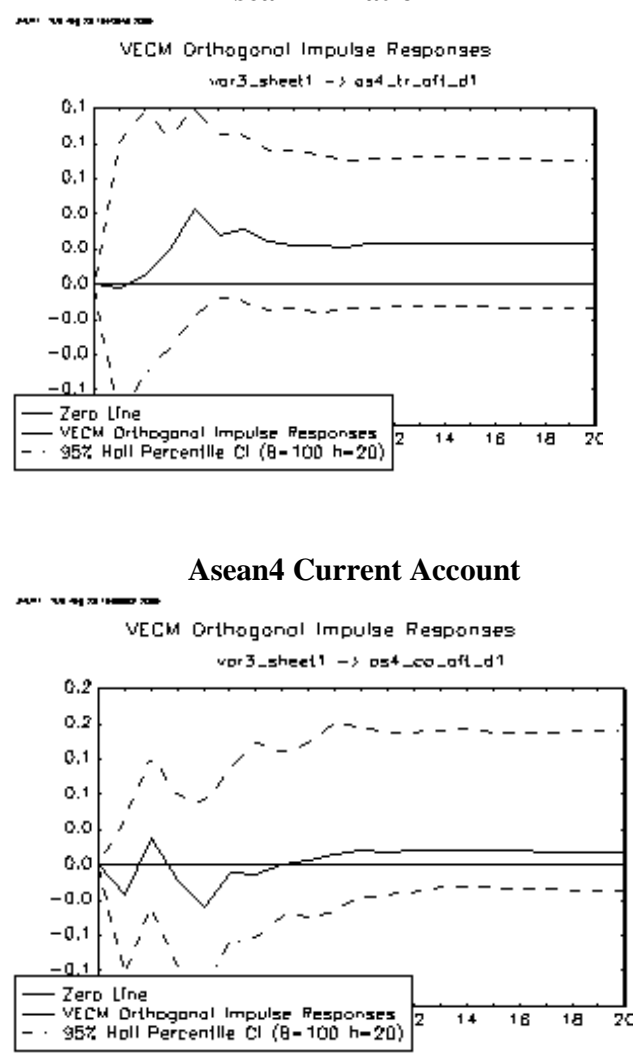

Figure 8 


\section{NOTES}

